\title{
STUDENTS' ACCEPTANCE OF THE USE OF GOOGLE CLASSROOM AS A PLATFORM IN BLENDED LEARNING
}

\author{
Aulia Khairani \\ Universitas Riau, Pekanbaru, Indonesia \\ Email: aulia.khairani1441@ student.unri.ac.id \\ Afrianto Daud \\ Universitas Riau, Pekanbaru, Indonesia \\ Email: aburaudha@gmail.com \\ Mahdum \\ Universitas Riau, Pekanbaru, Indonesia \\ Email: mahdum uir@gmail.com
}

DOI: 10.35445/alishlah.v12i1.193

Accepted: April ${ }^{27 \text { th }}, 2020$. Approved: June $8^{\text {th }}, 2020$.

Published: June $30^{\text {th }}, 2020$

\begin{abstract}
This study aims to identify the students' acceptance level of the use of Google Classroom as a platform in Blended-learning and to compare the results between three departments of Language and Arts Department in FKIP of Universitas Riau. Data of this survey research were collected through an online survey using Google form and analyzed descriptively. The survey was distributed to all students and 205 of them responded to the survey coming from three departments: English Language and Arts Department, Indonesian Language and Arts Department, and Japanese Language and Arts Department in FKIP of Universitas Riau. The questionnaires in the survey used Technology Acceptance Model (TAM) proposed by Davis (1986) with four indicators to measure the students' acceptance: Perceived Usefulness (PU), Perceived Ease of Use (PEU), Behavioral Intention (BI), and Actual System Use (AU). The students' acceptance levels in terms of Perceived usefulness $(62,8 \%)$ was in a very good category; Perceived Ease of Use (67,2\%) was in a very good category; Behavioral Intention (69\%) was in a very good category, and Actual System Use (48,55\%) was good category. The result shows that the level of the students' acceptance of Google Classroom, in general, is Very Good (62\%). It means, the students positively accepted Google Classroom as a platform in blended-learning. Behavioral Intention was the indicator with the highest percentage (69\%) which explains that students are interested and intend to increase their use of the Google Classroom.
\end{abstract}


Al-Ishlah: Jurnal Pendidikan - ISSN: 2087-949o (p); 2597-940X (e)

Vol. 12, No. 1 (2020)

Data also shows that out of the three departments, The English Language and Arts Department has the highest average mean score (3.67) followed by the Indonesian Language and Arts Department (3.57) and Japanese Language and Arts Department (3.54). This study implies that English department students experienced more acceptance in using the Google Classroom compared to the other two departments.

Keywords: Acceptance, Google Classroom, Blended learning

\title{
STUDENTS' ACCEPTANCE OF THE USE OF GOOGLE CLASSROOM AS A PLATFORM IN BLENDED LEARNING
}

\begin{abstract}
Abstrak
Penelitian ini bertujuan untuk mengidentifikasi tingkat penerimaan siswa tentang penggunaan Google Classroom sebagai platform dalam Blended-learning dan untuk membandingkan hasil antara tiga Departemen Bahasa dan Seni di FKIP Universitas Riau. Data penelitian survei ini dikumpulkan melalui survei online menggunakan Google Formulir dan dianalisis secara deskriptif. Survei ini didistribusikan kepada semua siswa dan 205 dari mereka menanggapi survei yang berasal dari tiga departemen: Departemen Bahasa dan Seni Bahasa Inggris, Departemen Bahasa dan Seni Indonesia, dan Departemen Bahasa dan Seni Jepang di FKIP Universitas Riau. Kuesioner dalam survei menggunakan Technology Acceptance Model (TAM) yang diajukan oleh Davis (1986) dengan empat indikator untuk mengukur penerimaan siswa: Perceived Usefulness (PU), Persepsi Penggunaan yang Mudah (PEU), Behavioral Intention (BI), dan Actual Penggunaan Sistem (AU). Tingkat penerimaan siswa dalam hal manfaat yang dirasakan (62,8\%) berada dalam kategori yang sangat baik; Persepsi Kemudahan Penggunaan (67,2\%) berada dalam kategori sangat baik; Behavioral Intention (69\%) berada dalam kategori sangat baik, dan Penggunaan Sistem Aktual (48,55\%) adalah kategori baik. Hasilnya menunjukkan bahwa tingkat penerimaan siswa terhadap Google Classroom, secara umum, Sangat Bagus (62\%). Artinya, siswa menerima Google Classroom secara positif sebagai platform dalam blended-learning. Behavioral Intention adalah indikator dengan persentase tertinggi (69\%) yang menjelaskan bahwa siswa tertarik dan berniat untuk meningkatkan penggunaan Google Classroom mereka. Data juga menunjukkan bahwa dari tiga departemen, Departemen Bahasa dan Seni Bahasa Inggris memiliki skor rata-rata rata-rata tertinggi $(3,67)$ diikuti oleh Departemen Bahasa dan Seni Indonesia (3,57) dan Departemen Bahasa dan Seni Jepang (3,54). Studi ini menyiratkan bahwa mahasiswa jurusan bahasa Inggris mengalami lebih banyak penerimaan dalam menggunakan Google Classroom dibandingkan dengan dua jurusan lainnya.
\end{abstract}

Keywords: Acceptance, Google Classroom, Blended learning 
Vol. 12, No. 1 (2020)

\section{INTRODUCTION}

As technology is advancing and teachers are facing a new generation, teachers should be able to adjust themselves with this development. The adjustment, in particular, should happen in the way the teachers conduct their class. They should adopt the advancement of technology in the process of learning. As Afrianto (2018, p.4) reminds, "Teachers of this digital age, for instance, should be teachers with the 21 st-century learning mindset, possess digital literacy, keep learning new things, and should be able to make use of opportunities provided by the IR 4.0 for their better teaching."

Teachers can use technology in the class as a learning tool and or media for learning. One of the advantages of digital technology is that it can be used by the teachers for conducting virtual learning or E-learning. Permendikbud of Republic of Indonesia No. 109, subsection 1 (4) 2013 explains that E-learning is a learning process that utilizes technology, information, and communication (ITC) based learning for the benefit of learning that can be accessed by students anytime and anywhere. The government has set rules regarding the use of E-learning in the learning process, which will help make learning more accessible and more effective.

There are several examples of E-learning tools or LMS (Learning Management System) that are now available. These include Moodle, Edmodo, Schoology, Google Classroom, and some other platforms. According to Jakkaew and Hemrungrote (2017) in Jeya \& Brandford (2019), one of the popular LMS applications is Google Classroom. This Google Classroom is one of the applications released by Google Inc., as part of its contribution to the advancement of education. This is a free application which can be used for teachers to manage their class virtually. They can use it, for example, to make an announcement, post an assignment, upload learning materials, and also to mark students' works (Daud, 2019).

This application is an excellent alternative app to enable teachers to conduct a virtual class in addition to their traditional offline classes. Combining this traditional classroom teaching with modern online-based teaching is called blended learning. Blended learning is an activity conducted by lecturers and teachers that develop both simple and complex learning styles. It is simple because blended learning is a classroom face-to-face integrated with online learning experiences (Garison and Kanuka, 2004).

Some previous studies indicate that the use of google classroom has been found effective to enhance students learning. A study by Jeya \& Brandford (2019), for instance, shows that Google Classroom increases a positive impact on the usage of the pedagogical process. They also found that students are interested 
in using Google Classroom as mobile learning which is more flexible. Another study by Heggart and Yoo (2018) also shows that Google Classroom can increase student participation in learning and improve classroom dynamics.

However, there is a gap in a study of Google Classroom. A study from Azhar \& Iqbal (2018), showed the results from their study that the teachers perceived Google Classroom as only a facilitation tool that can be used for documents and basic classroom management without get a significant impact on teaching methodologies. Meanwhile, according to Ramadhani et al (2019), the students at the second level of high school felt passionate, motivated, and eager to take part in learning using Google Classroom. The results from the study indicate that Google Classroom serves a new experience for them to take part in a lesson both in class and outside the classroom.

The study from Clay J.R et al (2019) also showed positive results. The analyzed the results of the implementing of Google Classroom, the students' engagement levels increased and the implementation of Google Classroom was highly supported by the students. The study from Christiano \& Triana (2019) also revealed that Google Classroom made the course easy to pursue and it's friendly to the environment. The students thought that it was the best way to keep in touch with their teacher outside the classroom and they keep contact in real-time progress of activities. With using Google Classroom, it makes the learning process as the collaborative process instead of the classic learning process.

In the Indonesian context, the use of this Google Classroom for blended learning is relatively new for both teachers and students. This is not only the case at schools but also on campuses, especially at Universitas Riau. It seems that there are still few lecturers who apply the blended-learning style in Universitas Riau. Not all lecturers and students are familiar and use this Google Classroom. Some lecturers prefer to use traditional ways of teaching because they probably are not familiar yet with how to operate the tools that required technology and the internet. However, there are several lecturers who have used this application in their classrooms.

This particular study investigated the students' acceptance who already experienced using Google Classroom in their class for learning. This study hopes to find out the students' acceptance on this application indicating whether using Google Classroom is helpful and practical for their learning process.

\section{METHOD}

The research applied descriptive quantitative research design using survey as the method of data collection. The population of this research is all students of 
Vol. 12, No. 1 (2020)

Language and Arts Department, Faculty of Teachers Training and Education in Universitas Riau. The samples were selected using proportional stratified sampling technique by which 205 students were finally selected as the samples.. Data were collected using online questionnaires making use of google form. The instrument of this research is a set of questionnaire adopted from TAM design by Davis (1986). The online questionnaire contains statements from TAM in the form of likert scale divided into a scale from one to five, namely Strongly Disagree, Disagree, Neutral, Agree, and Strongly Agree. Indicator to measure the students' acceptance of Google classroom, namely: Perceived Usefulness, Perceived Ease of Use, Behavioral Intention to Use, and Actual Use. Perceived Usefulness is the indicator to see the students' perception towards the application whether it is useful or not. Perceived Ease of Use is the indicator to measure whether the application is easy to use or not for the students. Behavioral Intention is the indicator to measure the students' acceptance using Google Classroom, whether they're interested or not. Actual System Use is the indicator to find out if the respondents are using the application frequently or in their daily basis.

The only survey accepted responses until the number of respondents needed was accomplished. There were 205 students who answered and or responded the questionnaire. The data were analyzed with descriptive statistics. Then, the data were calculated to find out the level of acceptance by the result of the index percentage of each indicator. Data were then interpreted using interpretation scores as proposed by Sugiyono (2009).

Table 1 Interpretation of Scores

\begin{tabular}{cc}
\hline $\begin{array}{c}\text { Interval of Frequency of } \\
\text { the Students' Acceptance }\end{array}$ & $\begin{array}{c}\text { Classification Level of the } \\
\text { Students' Acceptance }\end{array}$ \\
\hline $81 \%-100 \%$ & Excellent \\
$61 \%-80 \%$ & Very Good \\
$41 \%-60 \%$ & Good \\
$21 \%-40 \%$ & Poor \\
$0 \%-20 \%$ & Very Poor \\
\hline
\end{tabular}

(Sugiyono, 2009) 
Al-Ishlah: Jurnal Pendidikan - ISSN: 2087-949o (p); 2597-940X (e)

Vol. 12, No. 1 (2020)

\section{FINDING AND DISCUSSION}

\section{The Results of the Questionnaire}

The following data on the Table 2 show the students' acceptance of the use of Google Classroom as a platform in blended learning from 205 participating students. The data were analyzed and calculated to find out the mean score and the index percentage. The results of the index percentage show the level of the students' acceptance of the use of Google Classroom as a platform in blended learning.

Table 2 Students' Acceptance of the use of Google Classroom

\begin{tabular}{cccccc}
\hline Indicator & Sample & Minimum & Maximum & Mean & $\begin{array}{c}\text { Index } \\
\text { Percentage }\end{array}$ \\
\hline $\begin{array}{c}\text { Perceived Usefulness } \\
\text { (PU) }\end{array}$ & 205 & 1 & 5 & 3.74 & $62,8 \%$ \\
$\begin{array}{c}\text { Perceived Ease of Use } \\
\text { (PE) }\end{array}$ & 205 & 1 & 5 & 4.00 & $67,2 \%$ \\
$\begin{array}{c}\text { Behavioural Intention } \\
\text { (BI) }\end{array}$ & 205 & 1 & 5 & 4.10 & $69 \%$ \\
$\begin{array}{c}\text { Actual System Use } \\
(\text { AU) }\end{array}$ & 205 & 1 & 5 & 2.89 & $48,55 \%$ \\
\hline
\end{tabular}

Table 2 summarises the mean value and index percentage for each indicator. The First indicator, Perceived Usefulness (PU), got a mean score of 3.74 with index percentage of $62,8 \%$, meaning that this indicator is classified in the very good category. The second Indicator, Perceived Ease of Use (PE), got a mean score of 4.00 with index percentage of $67,2 \%$, meaning that this indicator is classified in the very good category. The third indicator, Behavioral Intention (BI), got a mean score of 4.10 with index percentage of $69 \%$, meaning that this indicator is classified in the very good category. The fourth indicator, Actual System Use (AU), got a mean score of 2.89 with index percentage of 48,5\%, meaning that ths indicator is classified in the good category.

In conclusion, the students are interested in using Google Classroom as it shows on the results of the third indicator, Behavioral Intention (BI) with a mean score of 4.10, meaning that this is the highest mean score and also the highest index percentage with 69\%. However, they are not using Google Classroom 
Al-Ishlah: Jurnal Pendidikan - ISSN: 2087-949o (p); 2597-940X (e)

Vol. 12, No. 1 (2020)

actively as it shows in the fourth indicator, Actual System Use (AU) with a mean score 2.89 and the lowest index percentage with 48,55\%. Detailed description of the data in table 2 can be seen in the following table:

\section{a. Analysis of Perceived Usefulness (PU)}

This particular section refers to question on how the students see the usefulness of google clasroom for their learning. This section consists of seven subsections as seen below. Table 3 summarises students' responses on this particular section - perceived usefulness.

Table 3 Students' Acceptance of the use of Google Classroom by SubIndicators

\begin{tabular}{cccccc}
\hline Variable & Sample & Minimum & Maximum & Mean & $\begin{array}{c}\text { Index } \\
\text { percentage }\end{array}$ \\
\hline PU1 & 205 & 2 & 5 & 3.91 & $65,7 \%$ \\
PU2 & 205 & 2 & 5 & 3.57 & $59,9 \%$ \\
PU3 & 205 & 1 & 5 & 3.88 & $65,2 \%$ \\
PU4 & 205 & 2 & 5 & 3.65 & $61,4 \%$ \\
PU5 & 205 & 1 & 5 & 4.27 & $71,7 \%$ \\
PU6 & 205 & 1 & 5 & 3.40 & $57 \%$ \\
PU7 & 205 & 1 & 5 & 3.51 & $59 \%$ \\
& & & & $\mathbf{3 . 7 4}$ & $\mathbf{6 2 , 8 \%}$ \\
\hline
\end{tabular}

PUI refers to the statement in the questionnaire, Google Classroom enhances my efficiency. The data shows that it got the mean value of 3.91 with calculation of the index of $65,7 \%$. This means that this particular point is categorised in the very good category. It further can be concluded that most of respondents agree that Google Classroom enhances their efficiency of learning.

PU2 refers to the statement in the questionnaire, Google Classroom enhances my learning productivity. The data shows that it got the mean value of 3.57 with calculation of the index of $59,9 \%$. This means that this particular point is categorised in the very good category. It further can be concluded that most of respondents agree that Google Classroom enhances their learning productivity.

PU3 refers to the statement in the questionnaire, Google Classrom enables me to accomplish tasks more quickly. The data shows that it got the mean value of 3.88 with calculation of the index of $65,2 \%$. This means that this particular point is categorised in the very good category. It further can be concluded that most of 
Al-Ishlah: Jurnal Pendidikan - ISSN: 2087-949o (p); 2597-940X (e)

Vol. 12, No. 1 (2020)

respondents agree that Google Classroom enables them to accomplish tasks more quickly.

PU4 refers to the statement in the questionnaire, Google Classroom improves my performance. The data shows that it got the mean value of 3.65 with calculation of the index of $61,4 \%$. This means that this particular point is categorised in the very good category. It further can be concluded that most of respondents agree that Google Classroom improves their performance.

PU5 refers to the statement in the questionnaire, Google Classroom saves my time. The data shows that it got the mean value of 4.27 with calculation of the index of $71,7 \%$ This means that this particular point is categorised in the very good category. It further can be concluded that most of respondents agree that Google Classroom saves their time.

PU6 refers to the statement in the questionnaire, Google Classroom doesn't have any distinctive useful features. The data shows that it got the mean value of 3.40 with calculation of the index of $57 \%$. This means that this particular point is categorised in the good category. It further can be concluded that most of respondents agree that Google Classroom doesn't have any distinctive useful features.

PU7 refers to the statement in the questionnaire, Google Classroom is not applicable to all academic course. The data shows that it got the mean value of 3.51 with calculation of the index of $59 \%$. This means that this particular point is categorised in the very good category. It further can be concluded that most of respondents neither agree nor disagree that Google Classroom is not applicable to all academic course.

The description above indicate that most of the respondents accepted that the use of google classroom in learning can save their time $(71.7 \%)$. They also indicate that Google Classroom enhances their efficiency $(65,7 \%)$.

\section{b. Analysis of Perceived Ease of Use (PE)}

This particular section refers to question on how the students see the ease of use for google clasroom for their learning. This section consists of six subsections as seen below. Table 4 summarises students' responses on this particular section - Perceived ease of use. 
Al-Ishlah: Jurnal Pendidikan - ISSN: 2087-949o (p); 2597-940X (e)

Vol. 12, No. 1 (2020)

Table 4 Students' Acceptance of the use of Google Classroom by SubIndicators

\begin{tabular}{cccccc}
\hline Variable & Sample & Minimum & Maximum & Mean & $\begin{array}{c}\text { Index } \\
\text { percentage }\end{array}$ \\
\hline PE1 & 205 & 1 & 5 & 4.30 & $72,3 \%$ \\
PE2 & 205 & 1 & 5 & 4.13 & $69,4 \%$ \\
PE3 & 205 & 1 & 5 & 3.92 & $65,8 \%$ \\
PE4 & 205 & 1 & 5 & 4.37 & $73,4 \%$ \\
PE5 & 205 & 1 & 5 & 3.42 & $57,5 \%$ \\
PE6 & 205 & 2 & 5 & 3.88 & $65,2 \%$ \\
& Average & & & $\mathbf{4 . 0 0}$ & $\mathbf{6 7 , 2 \%}$ \\
\hline
\end{tabular}

PE1 refers to the statement in the questionnaire, Google Classroom is easy to use. The data shows that it got the mean value of 4.30 with calculation of the index of $72,3 \%$. This means that this particular point is categorised in the very good category. It further can be concluded that most of respondents agree that Google Classroom is easy to use.

PE2 refers to the statement in the questionnaire, Google Classroom enables me to access the course material. The data shows that it got the mean value of 4.13 with calculation of the index of $69,4 \%$. This means that this particular point is categorised in the very good category. It further can be concluded that most of respondents agree that Google Classroom enables them to access the course material.

PE3 refers to the statement in the questionnaire, Google Classroom is convenient and user friendly. The data shows that it got the mean value of 3.92 with calculation of the index of $65,8 \%$. This means that this particular point is categorised in the very good category. It further can be concluded that most of respondents agree that Google Classroom is convenient and user friendly.

PE4 refers to the statement in the questionnaire, Google Classroom allows me to submit my assignment. The data shows that it got the mean value of 4.37 with calculation of the index of $73,4 \%$. This means that this particular point is categorised in the very good category. It further can be concluded that most of respondents agree that Google Classroom allows them to submit their assignment. 
Al-Ishlah: Jurnal Pendidikan - ISSN: 2087-949o (p); 2597-940X (e)

Vol. 12, No. 1 (2020)

PE5 refers to the statement in the questionnaire, Google Classroom requires no training. The data shows that it got the mean value of 3.42 with calculation of the index of $57,5 \%$. This means that this particular point is categorised in the good category. It further can be concluded that most of respondents neither agree nor disagree that Google Classroom is require no training.

PE6 refers to the statement in the questionnaire, Google Classroom makes it easier to avoid future academic difficulties. The data shows that it got the mean value of 3.88 with calculation of the index of $65,2 \%$. This means that this particular point is categorised in the very good category. It further can be concluded that most of respondents agree that Google Classroom makes it easier to avoid the future academic.. The description above indicate that most of the respondents accepted that the use of google classroom in learning allows them to submit their assignment $(73,4 \%)$. They also indicate that Google Classroom is easy to use $(72,3 \%)$.

\section{c. Analysis of Behavioral Intention to Use (BI)}

This particular section refers to question on how is the students' behavioral intention of google clasroom for their learning. This section consists of three subsections as seen below. Table 5 summarises students' responses on this particular section - behavioral intention.

Table 5 Students' Acceptance of the use of Google Classroom by SubIndicators

\begin{tabular}{cccccc}
\hline Variable & Sample & Minimum & Maximum & Mean & $\begin{array}{c}\text { Index } \\
\text { percentage }\end{array}$ \\
\hline BI1 & 205 & 1 & 5 & 3.93 & $66 \%$ \\
BI2 & 205 & 1 & 5 & 4.35 & $73 \%$ \\
BI3 & 205 & 2 & 5 & 4.03 & $67,8 \%$ \\
& \multicolumn{2}{c}{ Average } & & $\mathbf{4 . 1 0}$ & $\mathbf{6 9 \%}$ \\
\hline
\end{tabular}

BI1 refers to the statement in the questionnaire, I intend to increase my use of the Google Classroom. The data shows that it got the mean value of 3.93 with calculation of the index of $66 \%$. This means that this particular point is categorised in the very good category. It further can be concluded that most of respondents agree that they intend to increase the use of the Google Classroom. 
$\mathrm{BI} 2$ refers to the statement in the questionnaire, It is worth to recommend the Google Classroom for other students. The data shows that it got the mean value of 4.35 with calculation of the index of $73 \%$. This means that this particular point is categorised in the very good category. It further can be concluded that most of respondents agree that it is worth to recommend the Google Classroom for other students.

$\mathrm{BI} 3$ refers to the statement in the questionnaire, I'm interested to use the Google Classroom. The data shows that it got the mean value of 4.03 with calculation of the index of $67,8 \%$. This means that this particular point is categorised in the very good category. It further can be concluded that most of respondents agree that they interested to use the Google Classroom.

The description above indicate that most of the respondents accepted that it is worth to recommend Google Classroom to other students (73\%). They also indicate that they are interested in using Google Classroom $(67,8 \%)$.

\section{d. Analysis of Actual System Use (AU)}

This particular section refers to question on how the students are actually using of google clasroom for their learning. This section consists of two subsections as seen below. Table 6 summarises students' responses on this particular section - actual system use.

Table 6 Students' Acceptance of the use of Google Classroom by SubIndicators

\begin{tabular}{cccccc}
\hline Variable & Sample & Minimum & Maximum & Mean & $\begin{array}{c}\text { Index } \\
\text { percentage }\end{array}$ \\
\hline AU1 & 205 & 1 & 5 & 2.65 & $44,6 \%$ \\
AU2 & 205 & 1 & 5 & 3.13 & $52,5 \%$ \\
& \multicolumn{2}{c}{ Average } & & $\mathbf{2 . 8 9}$ & $\mathbf{4 8 , 5 5 \%}$ \\
\hline
\end{tabular}

AU1 refers to the statement in the questionnaire, I use the Google Classroom on daily basis. The data shows that it got the mean value of 2.65 with calculation of the index of $44,6 \%$. This means that this particular point is categorised in the good category. It further can be concluded that most of respondents neither agree nor disagree use the Google Classroom on daily basis.

AU2 refers to the statement in the questionnaire, I use the Google Classroom frequently. The data shows that it got the mean value of 3.13 with calculation of the index of $52,5 \%$. This means that this particular point is 
Al-Ishlah: Jurnal Pendidikan - ISSN: 2087-949o (p); 2597-940X (e)

Vol. 12, No. 1 (2020)

categorised in the good category. It further can be concluded that most of respondents use the Google Classroom frequently.

The description above indicate that most of the respondents accepted that they use Google Classroom frequently $(52,5 \%)$.

\section{e. The Results of Descriptive Analysis from Each Department}

The average mean score form each indicator shows the results among the three departments which are; English Language and Art Department, Indonesian Language and Art Department, and Japanese Language and Art Department. The detailed score can be seen in the following Table 7:

Table 7 The Results of Descriptive Analysis from Each Department

\begin{tabular}{|c|c|c|c|c|c|}
\hline \multirow{2}{*}{ Department } & \multicolumn{4}{|c|}{ Indicators } & \multirow{2}{*}{$\begin{array}{c}\text { Average } \\
\text { Score }\end{array}$} \\
\hline & $\mathbf{P U}$ & $\mathbf{P E}$ & BI & $\mathbf{A U}$ & \\
\hline $\begin{array}{c}\text { English } \\
\text { Language and } \\
\text { Arts } \\
\text { Department }\end{array}$ & 3.47 & 4.14 & 4.22 & 2.88 & 3.67 \\
\hline $\begin{array}{c}\text { Indonesian } \\
\text { Language and } \\
\text { Arts } \\
\text { Department }\end{array}$ & 3.50 & 3.92 & 3.82 & 3.06 & 3.57 \\
\hline $\begin{array}{c}\text { Japanese } \\
\text { Language } \\
\text { And Arts } \\
\text { Department }\end{array}$ & 3.49 & 3.86 & 4.09 & 2.75 & 3.54 \\
\hline
\end{tabular}

The first indicator is Perceived Usefulness. The results show that most of the respondents from Indonesian Language and Arts Department agree that Google Classroom gives many benefits and they agree that it's useful with mean values is 3.50. However, Japanese Language and Arts Department on the second place with mean values is 3.49 and English Language and Arts Department with mean values is 3.47 .

The second indicator is Perceived Ease of Use. The results show that most of the respondents from English Language and Arts Department agree that Google Classroom is easy to use and operate and it helps them in sharing files and submitting tasks with mean values is 4.14 . However, Indonesian Language and 
Al-Ishlah: Jurnal Pendidikan - ISSN: 2087-949o (p); 2597-940X (e)

Vol. 12, No. 1 (2020)

Arts Department on the second place with mean values is 3.92 and Indonesian Language and Arts Department with mean values is 3.86.

The third indicator is Behavioral Intention. The results show that most of the respondents from English Language and Arts Department agree that they are interested using Google Classroom, they intend to using it and they are agreed that Google Classroom is worth to recommend to other students with mean values is 4.22. However, Japanese Language and Arts Department on the second place with mean values is 4.09 and Indonesian Language and Arts Department with mean values is 3.47 .

The fourth indicator is Actual system Use. The results show that most of the respondents from Indonesian Language and Arts Department are the highest number of users that using Google Classroom in their daily basis and using it frequently with mean values is 3.06. However, English Language and Arts Department on the second place with mean values is 2.88 and Japanese Language and Arts Department with mean values is 2.75 .

In conclusion, based on the average score from each department indicates that English Language and Arts Department (3.67) has the highest score. While Japanese Language and Arts Department (3.57) on the second and Indonesian Language and Arts Department (3.54) on the third.

As previously discussed that shows that the level of the students' acceptance of Google Classroom, in general, is Very Good (62\%). It means that the students positively accepted Google Classroom as a platform in blendedlearning. The results of this research are similar to some other studies on the same topic. A study from Riki Rahmad et al. (2019), for instance, shows that the lecturers and students feel that Google Classroom is easy to use and help them to manage classes. The students showed that their critical thinking level increased to medium level after the learning media in the form of Google Classroom was applied. Another study by Jeya \& Brandford (2019) reveals that Google Classroom is interactive and they found that Google Classroom increases a positive impact on the usage of the pedagogical process. They also found that students are interested in using Google Classroom as mobile learning which is more flexible. A study from Heggart \& Yoo (2018) indicates that Google Classroom increased students' participation in learning and improved classroom dynamics. It also revealed concerns around pace and user experience.

The result of this research answered the research questions about the level of students' acceptance of the use of Google Classroom as a platform in Blendedlearning especially in Language and Arts Department, Universitas Riau. From the 
Al-Ishlah: Jurnal Pendidikan - ISSN: 2087-949o (p); 2597-940X (e)

Vol. 12, No. 1 (2020)

result, it shows each of the index percentages of the level of students' acceptance from using Google Classroom as a platform in Blended-learning. On average, the results show that the students' acceptance in the level of very good $(62 \%)$.

Most of the results from three departments which are English Language and Arts Department (3.67), Indonesian Language and Arts Department (3.57), and Japanese Language and Arts Department (3.54) shows that they are agreed that Google Classroom gives them many benefits and make them more efficient in submit any task and download any material from the lecturer $(62,8 \%)$. Most of the respondents also agree that they interested to use Google Classroom and they intend to use it in the future (69\%). However, the last indicator which is Actual System Use shows that in the actual life the respondents are not using Google Classroom frequently nor on their daily basis $(48,5 \%)$. Most of the respondents are using Google Classroom only several times but they are already getting the benefits of using it $(62,8 \%)$. The respondents agree that Google Classroom will make work more efficient and it is easy to operate $(67,2 \%)$. The respondents agree to use it more often in the future $(69 \%)$.

From the data, it can be concluded that the average score from each department indicates that the English Language and Arts Department (3.67) has the highest score. While Japanese Language and Arts Department (3.57) on the second and Indonesian Language and Arts Department (3.54) on the third.

\section{CONCLUSION}

This study reveal that the level of the students' acceptance of Google Classroom in general is Very Good (62\%). It means, the students accepted Google Classroom as a platform in blended-learning. To be more specific, Behavioral Intention is the indicator with the highest percentage (69\%) which explains that students are interested and intend to increase their use of the Google Classroom. However, Actual System Use is the indicator with the lowest percentage $(48,5 \%)$ which means the respondents are rarely using the Google Classroom. It can be concluded that the respondents are actually interested and want to use Google Classroom but in the actual life they are not using it because the small number of lecturers who using Google Classroom as a platform in blended-learning and teaching in their class.

This study also found that most of the respondents agreed that Google Classroom gives many benefits for the students as explained in the first indicators. The respondents agree Google Classroom enhances their efficiency (65,7\%), 
Al-Ishlah: Jurnal Pendidikan - ISSN: 2087-949o (p); 2597-940X (e)

Vol. 12, No. 1 (2020)

Google Classroom enhances their learning productivity (59,9\%), Google Classroom enables the student to accomplish tasks more quickly $(65,2 \%)$, Google Classroom improves their performance $(61,4 \%)$ and Google Classroom saves their time $(71,7 \%)$. However, the respondents are, either agree or disagree Google Classroom doesn't have any distinctive useful features (57\%) and they agree that Google Classroom is applicable to all academic course (59\%). From the results on the second indicator, it can be concluded that Google Classroom has many benefits as a platform to help the learning process in the class. The respondents agree that Google Classroom is easy to use $(72,3 \%)$, convenient and user friendly $(65,8 \%)$. The respondents agree that they can easily access the course material $(69,4 \%)$ and submit their assignment without any problem $(73,4 \%)$. Even though that Google Classroom might requires a little bit training $(57,5 \%)$, the respondents strongly agree that Google Classroom will make the learning process easier to avoid future academic difficulties $(65,2 \%)$.

The third indicator identify the students' acceptance about the respondents behavioral intention to use. Three of the sub-indicators show the results are in the level of very good. The respondents agree that the respondents are interested in using the Google Classroom (67,8\%), and they intend to increase the use of Google Classroom (66\%). They also strongly agree to recommend Google Classroom to other students $(73 \%)$. However, the last indicator measures the students' acceptance about the actual system use. The results are in the level of good. This indicator shows that there are many of students that are neither using Google Classroom on their daily basis $(44,6 \%)$ nor using it frequently $(52,5 \%)$. Out of the three departments, English Language and Arts Department (3.67) has the highest average mean score followed by Indonesian Language and Arts Department (3.57) and Japanese Language and Arts Department (3.54). In conclusion, Google Classroom gives many benefits for the students and the respondents agreed $(62,8 \%)$. They are interested in using Google Classroom and they intend to increase the use of Google Classroom (69\%).

\section{REFERENCES}

Afrianto, A. (2018). Being a Professional Teacher in the Era of Industrial Revolution 4.0: Opportunities, Challenges and Strategies for Innovative Classroom Practices. English Language Teaching and Research, 2(1).

Azhar, K. A., \& Iqbal, N. (2018). Effectiveness of Google classroom: Teachers' perceptions. Prizren Social Science Journal, 2(2), 52-66. 
Al-Ishlah: Jurnal Pendidikan - ISSN: 2087-949o (p); 2597-940X (e)

Vol. 12, No. 1 (2020)

Clay, J. R., Teacher, M., \& Elementary, P. (2019). Impact of Google Classroom on Student Engagement. The eleventh annual science of wondering, 21.

Daud, A. (2019). Teaching Writing Using Google Apps For Education (GAFE). Indonesian Journal of Economics, Social, and Humanities, 1(1), 17-24. https://doi.org/10.31258/ijesh.1.1.2.

F. D. Davis. (1986). A technology acceptance model for empirically testing new end-user information systems: Theory and results. Massachusetts Institute of Technology.

Garrison, D. R., \& Kanuka, H. (2004). Blended learning: Uncovering its transformative potential in higher education. The internet and higher education, 7(2), 95-105.

Heggart, K. R., \& Yoo, J. (2018). Getting the Most from Google Classroom: A Pedagogical Framework for Tertiary Educators. Australian Journal of Teacher Education, 43(3).

Jakkaew, P., \& Hemrungrote, S. (2017). The use of UTAUT2 model for understanding student perceptions using Google classroom: A case study of introduction to information technology course. 2017 International Conference on Digital Arts, Media and Technology (ICDAMT), 205-209. https://doi.org/10.1109/ICDAMT.2017.7904962.

Jeya, A. K., \& Brandford, B. (2019). Google Classroom for mobile learning in higher education: Modelling the initial perceptions of students. Education and Information Technologies.

Ramadhani, R., Umam, R., Abdurrahman, A., \& Syazali, M. (2019). The effect of flipped-problem based learning model integrated with LMS-google classroom for senior high school students. Journal for the Education of Gifted Young Scientists, 7(2), 137-158.

Riki Rahmad, et al. (2019). Google Classroom Implementation in Indonesian Higher Education. Journal of Physics: Conference Series. 1175012153

Sugiyono. (2009). Metode Penelitian Kuantitatif, Kualitatif dan R\&D, Bandung: Alfabeta.

Wijaya, A. (2016). Analysis of factors affecting the use of Google Classroom to support lectures. In The 5th International Conference on Information Technology and Engineering Application (ICIBA2016). Bina Darma University. 